\title{
EESTI-SOOME KOODIVAHETUSE MITU NÄGU FACEBOOKI VESTLUSTE NÄITEL
}

\author{
Kristiina Praakli
}

Tartu ülikool

Ülevaade. Artikli keskmes on mitmehäälne diskursus. Põhitähelepanu lasub koodivahetuse funktsioonidel ning tähenduse loomisel Soomega seotud eesti keele kõnelejate Facebooki suhtluses. Lähtun koodivahetuse defineerimisel selle suhteliselt laiast määratlusest, mõistes koodivahetuse all eri keelte elementide vahelduvat kasutust suhtluses. Samas on koodivahetus heteroglossiline vahend, mille all mõistetakse eri hälte ning diskursuste paljusust. Selles ühinevad suhtluses osalejate hääled, sellega taasluuakse, edastatakse või esitletakse tähendust, mis on omakorda seotud varasemate diskursustega. Seega ei tähenda koodivahetus ainult öeldu edastamist, vaid selle abil toimub ka tähenduse loomine. Ainestiku diskursiivne analüüs näitab, et koodivahetus on nii funktsioon, vestluse kontekstile viitaja kui ka rühmadevaheliste piiride tõmbaja.

Märksõnad: koodivahetus, mitmehäälsus, tähenduse loomine, eesti keel, soome keel

\section{Taust ja teoreetiline raamistik}

Soome keel mängib kümnete tuhandete eesti keele kõnelejate elus üha suuremat rolli. Eesti keel on järjest enam kuuldav ja nähtav Soome linnamaastikel nii tavasuhtluses kui ka pildilis-sõnalises keeles (toidukauplused, välireklaamid) või institutsionaalses suhtluses (riigiasutuste eestikeelsed veebilehed). Eesti keele ja selle kõnelejate jõulist sisenemist Soome ja soome keeleruumi tähistavad kõige ilmekamalt Eesti sotsiaaldemokraatliku erakonna valimisreklaamid 2015. a kevadel Helsingi linnapildis sõnumiga „Ootame sind tagasi“. Soome statistikaameti andmeil elab Soomes 48087 inimest, kelle emakeel on eesti keel (Tilastokeskus 2016). Olgu võrdlusena öeldud, 
et Eesti taasiseseisvumiseelselt oli eestikeelseid elanikke Soomes 1394, sajandivahetusel 10 176, eelmise kümnendi lõpus 28493 (Tilastokeskus 2016). Eestikeelse elanikkonna kujunemist on mõjutanud Eesti ühinemine Euroopa Liiduga (2004) ning olukord Eesti tööturul. Kogukonna kujunemisel artiklis ma pikemalt ei peatu, neid teemasid on süvitsi käsitlenud mitmed uurijad (nt Jakobson jt 2012, Praakli 2009, 2010, Koreinik, Praakli ilmumas).

Praegune riigipiirideülene maailm on oluliselt muutnud arusaama suhtlusruumist. Keelekeskkonnad on laienenud virtuaalsfääridesse (Ehala jt 2014) ning üha suurem osa suhtlusest toimub veebiavarustes. Rände ja eeskätt hargmaisuse kontekstis tähendab see traditsiooniliste suhtlusstruktuuride (nt seltsiõhtud, omakeelne kultuuriline-klubiline tegevus jne) asendumist või paralleelselt nendega osalemist virtuaalsetes suhtlusruumides. Nii on ka Soomega seotud eesti keele kõnelejate põhilised suhtluskanalid arvukad veebivõrgustikud, mida ainuüksi Facebookis on paarkümmend: väiksemates paarsada, suurimas umbes kolmkümmend tuhat liiget.

Üleilmastumine, võõrkeelte parem kättesaadavus ja keeleoskuse ümbermõtestamine on avardanud mitmekeelsuse tähendust ja mõistmist. See nähtub selgesti ka suhtlusuuringute rõhuasetuste muutumises ning uute vaatenurkade esiletõusus, kus üksikkõneleja keeleliste vahendite kogu nähakse senisest laiemalt, keskendudes küsimusele, milleks kõneleja kõiki tema keelelises repertuaaris olevaid vahendeid kasutab. Kontseptsioonid, nagu polylingualism, polylanguaging (Jørgensen 2008, Jørgensen jt 2011), metrolingualism (Otsuji, Pennycook 2010) või translanguaging (Garcia, Wei 2014), signaliseerivad fookuse liikumist keelesüsteemide struktuuriliselt ühinemiselt mitmekeelsele kõnelejale ja tema tegevustele suhtluses. Neid ühendab ka kriitiline vaade keelele kui ideoloogilisele konstruktsioonile (detailne ülevaade Androutsopoulus 2013: 1-3, Garcia, Wei 2014, Jørgensen 2008, Jørgensen et al 2011, Lehtonen 2015, Otsuji, Pennycook 2010).

Siinse artikli keskmes on küsimus koodivahetuse funktsioonidest. Koodivahetuse definitsioone, teoreetilisi mudeleid ning üldse 
arusaamu mitmekeelsest suhtlusest on rohkesti (detailne ülevaade vt Verschik 2008: 2-24). Selles artiklis ma koodivahetuse mõistestikul, mudelitel, võrdlustel ning ühisosade otsinguil ei peatu, vaid keskendun kirjaliku ainestiku esitlusele ning sellele, milliseid lisavõimalusi mitme keele rakendamine suhtluses osalejatele pakub. Ka mõistet koodivahetus kasutan, viitamaks mis tahes üleminekutele, kus eesti keel soome keelega vahetub.

Üks esimesi koodivahetust vestluspragmaatilisest vaatenurgast avavaid teoreetilisi käsitlusi pärineb John Gumperzilt (1982). Gumperzi tööd on omakorda edasi arendanud ning nendega dialoogi astunud mitmed teised uurijad, eeskätt Peter Auer, kelle mitmekeelse suhtluse mudelid ning funktsioonide käsitluse teoreetiline raamistik on omakorda olnud vundamendiks teistele (vt detailne ülevaade Auer 1998: 1-28). Võõras pole teema ka eesti-soome koodivahetuse uurijatele (vt nt Frick 2010, Praakli 2009). Senised uurimused on avardanud eesti-soome mitmekeelsuse mõistmist nii struktuurilistest aspektidest - eeskätt Helka Riionheimo (2007, 2009, 2011, 2013a) ja Maria Fricki uurimused (2009, 2013, ka Riionheimo, Frick 2014) - kui ka koodivahetuse pragmaatikast (vt Frick 2009, Praakli 2009, Härmävaara, Frick ilmumas). Eesti-soome koodivahetust on valdavalt käsitletud suuliste ainestike, vähem kirjalike näitel (Frick 2010). Soomega seotud eesti keele kõnelejate elektroonilises suhtluses avalduvat koodivahetust pole autorile teadaolevalt varem käsitletud.

\section{Keeleainestik, keelejuhid ja analüüsimeetod}

Artikli keeleainestik pärineb Facebookist. Facebook on 2004. aastal Ameerika Ühendriikides loodud veebipõhine suhtlusvõrgustik, millel on umbes 1,3 miljardit kasutajat. Eestis on Facebooki kasutajaid 590000 (Hansalu 2015), Soomes 2,4 miljonit (Kärkkäinen 2015). Facebook pakub suhtluseks erinevaid platvorme: kasutaja isiklik profill, grupid (groups) ja lehed (pages). Gruppide suhtlust iseloomustab üks-mitmele suhtlus. Vestluse algatamiseks postitab grupi liige oma sõnumi rühma avalikule ajajoonele (n-ö seinale), kus 
see on kohe nähtav ning avatud edasiseks vestluseks kõikidele grupi liikmetele. Seega on ka kirjaliku suhtluse puhul tegu grupi liikmete ühiselt produtseeritud vestlustega.

Artikli ainestik hõlmab grupi liikmete postitusi 2015. ja 2016. aastal. Tekstikogu koosneb 421 tekstist. Artiklis võtan vaatluse alla 16 näidet. Kõik keelenäited on muudetud anonüümseks ning igasugune isikustamist võimaldav teave on keelenäidetest eemaldatud. Artikli autor on üks grupi (passiivne) liige. Vestlustemaatiliselt liigituvad postitused valdavalt olmeteemade hulka, hõlmates kõikvõimalikke teemasid, mis elukohariiki vahetanul ette võivad tulla (elukoha üürimine, tööpakkumised, töötasud, sotsiaalteenused, juriidiline nõustamine, ost-müük-vahetus jne). Vähem on kultuurispetsiifilisi ja päevapoliitilisi arutelusid.

Vaatluse all oleva suhtlusgrupi liikmed on üldjuhul noored täiskasvanud, kes kõnelevad emakeelena enamasti eesti keelt, mitmed ka vene või soome keelt. Rühma liikmete taust on heterogeenne, kuid neid ühendavad sarnased kogemused lähiajaloost ning ühine keele- ja kultuuritaust. Enamik neist on esimest korda soome keelega kokku puutunud täiskasvanuna, sestap on ka nende soome keele oskuse tase ebaühtlane; paljudel grupi liikmetel ei pruugi soome keelega veel ka pikemat suhtluskogemust olla. Samas on soome keel rühma liikmete üks ühiseid koode ning koodivahetuse rakendamine ei eeldagi teise kontaktkeele valdamist. Kõneleja on suuteline saavutama vestluseesmärgid ka siis, kui tal on teises keeles minimaalsed oskused (Auer 2013: 460). Viimast kinnitab ka selle artikli keeleainestik, millest nähtub, et koodivahetus on võimalik ka piiratud või sootuks olematu soome keele oskuse korral (vt näited 7 ja 8).

Kuigi varases kontaktsituatsioonis või vähese mitmekeelsuskogemusega kõnelejate puhul on koodivahetus pigem perifeerne, toob ainestik nähtavale individuaalsete koodivahetusmustrite paljususe. Kirjalik suhtlusruum peegeldab ka eesti netisuhtlusele omaseid jooni, nagu eriortograafia (nt grafeemide õ ja ü asendamine ö või y-ga), suulise kõne hääldust imiteeriv kirjapilt, suulise kõne foneetilised, leksikaalsed ja morfoloogilised jooned, laen- ja slängisõnad, 
emotikonid jne. Kirjaliku veebisuhtluse kohatine anonüümsus (alati pole teada, kes mingi kasutajanime taga peitub) võimaldab keelekasutajal keelt loovamalt kasutada, mis ei pruugi suulises kõnes tingimata aktsepteeritud olla.

Veebiainestiku analüüsimisel rakendan mikrosotsiolingvistika kvalitatiivset analüüsimeetodit, võttes appi ka vestlusanalüüsi vahendid. Keskendun suhtluses osalejate keelelistele valikutele ja funktsioonidele vestlustes ning tähendusloomele. Põhiküsimus lasub sellel, kuidas mitmekeelne diskursus luuakse ning mida soome keelega kirjalikus suhtlusruumis (Facebook) tehakse. Artikkel on jätk autori varasemale uurimistööle (Praakli 2009, 2010, 2014).

\section{Keelevalikud ja koodivahetuse mallid kirjalikus suhtlusruumis}

Avamaks koodivahetuse olemust, võtan esmalt vaatluse alla grupi liikmete keelelised valikud ning koodivahetuse põhilised mallid kirjalikus suhtlusruumis. Grupi postitused ning ühtlasi vestluste algatamised - laiemas mõttes vestluskeele valikud - toimuvad peaaegu eranditult eesti keeles, harva soome, eesti-soome või vene keeles. Tekstiline info edastatakse sageli fotode või linkide vormis, edasist vestlust algatamata. Soome keel postituste tervikliku keelevalikuna on aktuaalne soomekeelsete uudiste, kultuuriteadete, reklaamide jne edastamise puhul, sest need eeldavad sõnumi täpsust ning autentsuse säilitamist. Samas toimivad need kontekstivihjena, markeerides vestluse toimumise aega, ruumi ning vestluses osalejate seotust Soomega. Keelevalik annab vestlusesse astujatele ja seal osalejatele vihje, et soome keel on rühma liikmete üks ühiseid koode, mille kasutus on üldjuhul (aga mitte alati) aktsepteeritud. Kakskeelsed postitused viitavad ka võimalikele adressaatidele ning asjaolule, et postituse vastuvõtjateks võivad olla nii eesti kui soome keele kõnelejad. Seega näidatakse keele valikuga, et sõnum on suunatud mõlemale rühmale. Siinkohal tulebki appi koodivahetus: kõneleja näitab keele valikuga, kellele sõnum on suunatud. 
Näites 1 edastabki teemaalgataja võrgustiku liikmetele Eesti Vabariigi presidendi kakskeelse tervituse Soome iseseisvuspäeva puhul. Näites 2 algatab teine teemaalgataja soomekeelse uudislingi postitusega eesti päritolu sisserännanute (Soldiers of Odini liikmed) patrullimisest Soome tänavatel.

(1) A: Oikein hyvää itsenäisyyspäivää rakkaalle naapurillemme Suomelle ja kaikille suomalaisille! Soovin Soome Vabariigile ja kõikidele soomlastele õnne tänase iseseisvuspäeva puhul!

'A: Väga head iseseisvuspäeva meie armsale naabrile Soomele ja kõikidele soomlastele.'

(2) A: Virolaiset näyttävät mallia ja vartioivat Helsingin kaduilla.

'Eestlased näitavad eeskuju ja patrullivad Helsingi tänavatel.'

Postitusele järgneb link soomekeelse uudisega Virolaiset vartioivat Helsingin kaduilla. 'Eestlased patrullivad Helsingi tänavatel'.

Kuigi on selge, et koodivahetus on võrgustiku liikmete seas pigem tavapärane keelekasutuse viis, siis alati pikemaid üleminekuid soome keelele siiski ei aktsepteerita (vt näide 7).

Koodivahetuste struktuurist lähtuvalt on eesti-soome kirjalikus suhtluses avalduvad üleminekud valdavalt ühesõnalised (substantiivid, partiklid, verbid) ja esinevad vestluse põhikeeles (eesti keeles) kas fonoloogiliselt ja/või morfosüntaktiliselt integreeritul (näide 3) või integreerumata kujul, st säilitades terviklikult soome keele struktuuri (näide 4). Koodivahetus toimub peaaegu eranditult leksikaalsel tasandil, hõlmates valdavalt institutsionaalset sõnavara (maistraatti, poliisi), tänamis-, palumis-, tervitus- ja hüvastijätuvormeleid, interjektsioone (heippa, kiitos, moi jne) ning vandesõnu (voi perkele; mitä helvettiä jne). Ümberlülitumised on pigem perifeersed ja ulatuvad leksikaalselt tasandilt harva sügavamale morfosüntaktilisele tasandile.

Soome struktuuri terviklikku säilimist koodivahetuse protsessis olen valinud illustreerima näite 3 , mis kirjeldab tüüpilist ühesubstantiivilist ümberlülitumist. Kõneleja esitab grupi liikmetele küsimuse, kas erakorralisse vastuvõttu minnes tuleb tasuda 
visiiditasu. Küsimuse olulisimat infot kannab substantiiv päivystys (erakorraline vastuvõtt), mille küsimuse esitaja esitab kui selles vestluskontekstis relevantseima soome keeles. Kuigi kõneleja keelelisse repertuaari kuuluvad sel teemal ilmselt ka eestikeelsed vahendid (erakorraline meditsiin, EMO jne), võimaldab grupi liikmetega jagatav ühine kood ning tegutsemine ühises soomekeelses suhtlusruumis tarvitada soome keele pakutavaid vahendeid. Koodivahetuse morfoloogilise struktuuri mõttes järgib küsimuse esitaja terviklikult soome illatiivi struktuuri (päivystykseen).

(3) Hei! Rumal küsimus vb. Kui lähen päivystykseen kas maksan ka selle nn polikliinikumaksu?

soome päivystys 'erakorraline vastuvõtt'

Koodivahetuse teadlik rakendamine on ka kõneleja üks võimalusi edastada kultuurispetsiifilist teavet, mille asendamine omakeelse vastega pole ekvivalendi puudumise tõttu alati otstarbekas ega pruugi mõistesisu ikkagi avada. Näites 4 esitab teemaalgataja grupi liikmetele küsimuse ning saab sellele kaks asjakohast vastust. Neist esimene, C, annab teemaalgatajale pikema eestikeelse vastuse Soome koolilõputraditsioonide kohta, kasutamata selleks kordagi soome keelt. Vestlusesse sekkuv D vastab aga ühesõnalise üleminekuga soome keelele - penkkarit! -, tuues vastusega sisse vestluse toimumise kultuuriruumi.

(4) A: Miks on Mechelinkatu ja ka mujal täis maha pillatud komme nii et kõik urvitavad korjama?

B: Mingi kommionu on liikvel:)

C: Abiturentidel hakkab eksamihooaeg ja selline on Soomlaste komme. Enne eksamihooaega tehakse üks suur sõit autodega ja visatakse maiust.

\section{D: Penkkarit!}

soome penkkarit, penkinpainajaiset '12. klasside õpilastel õppetundide lõppemist ning eksamiperioodi algust tähistav pidu’ 
Soome keele häälikulise ja grammatilise struktuuri terviklik ülekandmine vestluse põhikeelde on koodivahetuse protsessis eesti keele kõnelejate kirjalikes vestlustes pigem marginaalne, markeerides niisugustel juhtudel teadlikku keelelist käitumist diskursusstrateegilistel eesmärkidel. Kahe morfoloogiarikka lähisugulaskeele vahetus kontaktsituatsioonis on koodivahetuse üheks iseloomulikuks mustriks selles osalevate ühikute (enamasti substantiivid ja verbid) häälikuline kohandamine kõneleja emakeele päraseks ning elementide morfoloogilis-süntaktilises käitumises lähtumine vestluse põhikeele (eesti keel) struktuurist. Soome elementide integreerimine põhikeelde võib variatsioonide- ja kõnelejakesksete variantide rohke olla ka ühe ja sama elemendi lõikes, nagu näeme siinses artiklis substantiivi henkilötunnus kasutuse puhul (vt näited 9 ja 10).

Näited 4 ja 5 illustreerivadki soome ühikute sihtkeelepäraseks kohandamise fonoloogilisi ja morfoloogilisi protsesse. Vestlustemaatiliselt on mõlema postituse sisu ja eesmärk rühma liikmetelt teabe küsimine või nende teavitamine formaalsetest protsessidest Soome kolimisel. Leksikaalsetest elementidest sisaldavad mõlemad postitused institutsionaalset sõnavara markeerivaid vahendeid, mis on ühtlasi ainsad koodivahetuses osalevad elemendid. Esimesena vaatluse alla tulevas näites näeme soome ühikute esinemist nominatiivi vormides. Substantiividest kolm - poliisi (politsei, politseijaoskond), maistraatti (elanikeregister) ja verotoimisto (maksuamet) - on häälikulises mõttes läbinud mitmed eesti keele päraseks kohandamise protsessid, nagu lõpukadu (vokaallõpuliste substantiivide lühenemine, vrd poliisi vs poliis, maistraatti vs maistraat) ja kaksikkonsonantide lühenemine (maistraatti vs maistraat). Eesti keele kõnelejate suulises kõnes maksuameti tähenduses esinev vero markeerib liitsubstantiivi lühenemist ning põhitähenduse ülekannet üksiksubstantiivile vero. Siinkohal nähtub selge erinevus soome ühiskeelega, kus keelend vero tähendab maksu või lõivu, kuid mitte maksuametit. Asutuse nime tähistavad soome keeles verotoimisto või verovirasto. Soome rahvapensioniameti (Kansaneläkelaitos) 
lühendatud nimekuju KELA on samas vormis ja tähenduses kasutusel ka Soomega seotud eestlaste kirjalikus ja suulises suhtluses.

(4) Nimelt kadunud kõik paberid seoses soome kolimisega - poliis, maistraat, vero, kela.

soome poliisi 'politsei, politseinik, politseijaoskond', maistraatti 'elanike register', vero 'maks, lõiv', KELA 'rahvapensioniamet'

Eelmises näites illustreeritud elementide morfosüntaktilist integreerumist kirjeldab näide 5. Koodivahetuses osalevate keelendite morfosüntaktiline käitumine pakub mitmeid tõlgendusvõimalusi. Leksikaalsest aspektist vaadatuna on maksuameti tähenduses esinev vero moodustatud liitsubstantiivi lühendamise teel, kus asutuse põhitegevusele ning institutsioonile viitab liitsõna esikomponent vero (maks). Kõneleja järgib eesti sõnajärge ja inessiivi kasutust soome tüvele eesti inessiivi tunnuse $-s$ aglutinatiivse liitmise teel. Analoogset morfoloogilist integreerumist näeme ka politseijaoskonda tähistava substantiivi poliisi puhul. Keelendi esinemisvorm pakub kaks tõlgendusvõimalust: kõneleja järgib soome kõnekeelele omast lühenenud tunnusega inessiivi kasutust (-s vs -ssa/-ssä), mis on lähedane inessiivi kasutusele eesti keeles, või tuleb kõneleja keeleliste valikute puhul tõenäolisemaks pidada analoogiapõhist lähtumist eesti inessiivi kasutusest (politseis), kuna soome keel eeldab siinkohal väliskohakäänete kasutust kas vormide poliisilaitoksella või poliisilla kujul. Eesti keele morfoloogilisest struktuurist lähtub ka kela kasutus, mis esineb eesti lõputa genitiivis (vrd sm kelan), eesti keele pärane on ka lause sõnajärg. Liitsubstantiivi henkilötunnus tarvitust võib vaadata nii leksikaalsest kui morfoloogilisest aspektist. Esimesel juhul ei saa välistada kummagi kontaktkeele leksikaalsete vahendite põhjal kakskeelse kompromissvormi moodustumist, morfoloogilisest aspektist vaadatuna võib substantiivi kasutust tõlgendada analoogiapõhise ülekandena eesti malli alusel (vrd sm tunnus : tunnuksen : tunnusta : tunnukset; ek tunnus : tunnuse : tunnust : tunnused). 
(5) A: /.../ Tulime soome ilma igasuguste paberiajamisteta, kohe koos mööbli ja asjadega. Saime korteriomanikuga kokku, kirjutasime lepingu õues, laadisime asjad tuppa ja läksime sama õhtu tööle. Esimesel vabal päeval käisime veros. Saime ajutised henkilötunnused ja siis töötasime-elasime aasta soomes ilma poliisis käimata ja kela asju ajamata.

soome poliisi 'politsei, politseinik, politseijaoskond', maistraatti 'elanike register', vero 'maks, lõiv', KELA 'rahvapensioniamet'

Sama fraasi ulatuses võivad koodivahetuses osaleda nii põhikeele kui ka lähtekeele struktuuri järgivad üleminekud (näide 6). Koodivahetuse mitmekeelsust markeerivas ning selle referatiivset funktsiooni täitvas üleminekus näeme nii soome elemendi eesti keelde integreeritud kasutust (eesti lõputa genitiiv kirumisväljendi saatana puhul) kui ka soome keele tervikliku morfoloogilise struktuuri säilimist substantiivi virolaiset mitmuse nominatiivi kasutuses. Mitmehäälsuse aspektist vaatlen näidet artikli lópuosas.

(6) A: Käisime mehega just poliisis end siia elama registreerimas. Esialgu vaatas ametnik kohe pilguga „saatana virolaiset“. /.../

Soome saatanan virolaiset 'pagana, kuradi eestlased'

Kuigi on selge, et koodivahetus on võrgustiku liikmete seas pigem tavapärane keelekasutuse viis, pole üleminekud soome keelele alati aktsepteeritud, nagu illustreerib näide 7 .

(7) A: Head aega töölisklass, tere tulemast pagulased

B: Suomessa pidetään somaleita luotettavimpinä kuin eestiläisiä.1990luvulla, kun alkoivat tulla Suomeen niin suomalaisille luvatiin että eivät vie suomalaisten työpaikkoja ja ne ovat sanansa pitäneet.

'Soomes peetakse somaale usaldusväärsemateks kui eestlasi. 1990ndatel, kui hakkasid Soome tulema, siis soomlastele lubati, et nad ei võta soomlaste töökohti ära ja nad on oma sõna pidanud.'

C: Suomalaiset on sen verran laiskoja, että sen takia virolaiset „vie“ työpaikkoja. Jos nei eivät olisi laiskoja ja työnlaatu olis melkein sama ku virolaisten, sit ei olisi hätää. 
'Soomlased on sel määral laisad, et selle pärast eestlased "võtavad“ töökohad ära. Kui nad ei oleks laisad ja nende töökvaliteet oleks peaaegu sama nagu eestlastel, siis ei oleks häda.'

B: B, superlaiskoja suomalainen ei viitsi tehdä työtä alle 25 euroa verokirjalla (tunti) minkä tyhmät tekee 5 euro mustana mutta koko päivän.

'B, superlaisk soomlane ei soovi teha tööd vähem kui 25 eurot koos maksudega (tund), mille lollid teevad ära viie euro eest mustalt, kuid kogu päeva.'

D: Miks te soome keeles kirjutate omavahel? On äge?

E: Eputavad

F: А нам соровно....

'A meil suva ....'

Vestluse algataja postitab sisserännet puudutava uudise ning avab vestluse sõnadega head aega töölisklass, tere tulemast pagulased. Avapostitusele järgneb kahe vestlusesse astuja vahel pikem soomekeelne arutelu eestlaste-soomlaste tööefektiivsuse teemadel. B ja C vahelisse soomekeelsesse diskussiooni sekkub järgmises voorus $D$, kes teeb märkuse soome keele kasutamise ja selle võimalike põhjuste kohta: Miks te soome keeles kirjutate omavahel? On äge? D-le sekundeerib ühesõnalise vastusega $\mathrm{E}$, kes pakub $\mathrm{D}$ esitatud küsimusele vastuseks, et eputavad. Arutelu lõpetab vestlusesse sekkuv F, kes tsiteerib lauset Vene filmimuusika klassikast $A$ нам все равно.

Rühma liikmete heterogeenne taust nähtub ka nende soome keele oskusest, mis on ühtlasi mitme vestluse põhiteema. Grupisisesed vestlused soome keele oskuse teemadel viitavad selgelt asjaolule, et kuigi soome keelt võib kasutada ka ebasümmeetrilise oskuse puhul vägagi erinevalt, pole soome keele mis tahes kasutusviis aktsepteeritud: soome keele väära kasutamise üle heidetakse vähem või rohkem varjatud kujul nalja, tehakse keelelisi parandusi, vaieldakse õigekeelsusnormide üle.

Näites 8 algatab vestluse sel hetkel veel Eestis elanud eestlanna, kes esitab grupi liikmetele küsimuse perega Soome kolimise kohta. 
Vestluses osaleb paarkümmend eesti keele kõnelejat, teemaalgataja küsimus kogub 139 vastust. Arutelu lõpuosas tõstatub põhiteema kõrvale küsimus soome keele oskusest. Rõhuasetuse muutumine johtub ühe vestluses osaleja viisist kasutada soome substantiivi henkilötunnus (isikukood) variandis engelitunnus, mis assotsieerub vestluses osalejatele sõnaga inglitunnus (sm enkeli 'ingel'). Originaalpostituse täpne sõnastus pole enam tuvastatav, sest postitaja on selle eemaldanud.

Substantiivi henkilötunnus tavapärastest variatsioonidest (nt hengelotunnus, hengilötunnus, henkar jne) eesti keele kõnelejate kasutuses selgelt eristuv keelend pälvib kohe grupi liikmete tähelepanu. On ilmne, et substantiivi vestlusesse toonud grupi liikme soome keele oskus on veel vähene või on kõneleja omandanud substantiivi puhul väära vormi, kandes keelendile üle eesti suulisele kõnele tüüpilised häälikulised omadused - sõnaalguse h-konsonandi mittehääldamine ja sõnasisene häälikute kadu - , mis omakorda kanduvad üle kirjalikku keelde. Resultaadiks on vorm, mis lahkneb substantiivi normipärasest kasutusest soome keeles nii häälikulise kuju kui ka semantiliste omaduste poolest. Substantiivi hääldust imiteerida püüdev kõneleja annab sellele kirjalikus kasutuses tahtmatult uue, humoorika tähenduse, kõneldes isikukoodi asemel hoopiski inglitunnusest. Kõneleja olematu või vähene soome keele oskus ei võimalda aru saada ega osaleda teiste vestlusesse sekkujate keelemängust ja naljatamisest, mille keelendi väärkasutus ja substantiivile tahtmatult antud lisatähendus kaasa toovad.

(9) B: engelitunnus:D, ikka henkilötunnus

D: sõna "engelitunnus" toob kananaha selga :D/.../

C: kust seda engelitunnust saab? :D surnuaiast?

D: kui tiibu seljas pole $*$ siis surnuaiast.

Soome henkilötunnus 'isikukood'

Kui esimese näite puhul saab soome keelest piiritõmbamise vahend keelt valdavate ja mitteoskava(te) grupi liikmete vahel, lubades soome keele oskajatel inglitunnust edukalt rakendada ka keelemängus, 
andmata keelendi esmakasutajale kordagi selget vihjet selle kohta, millise lisatähenduse eesti kõnekeelele tuginev häl̈ldusmall sõnale annab, siis näite 9 puhul antakse postituse algatajale selged juhtnöörid soome keele õigeks kasutamiseks. Vestluse algatanud A esitab detailse ülevaate Soome elanikuks registreerimiseks vajaliku dokumentatsiooni kohta. Kuigi postitus sisaldab mitmeid ümberlülitumisi soome keelele (käisime poliisis ja maistradis ära, kuu algusepoole poliisis käisime) ning soome keele mittenormipärast kasutust, ei pälvi need võrgustiku liikmete tähelepanu. Tähelepanutõmbajaks saab taaskord (nagu ka näites 8) substantiivi henkilötunnus eripärane kasutus - näites 10 kujul hengelotunnused -, mis algatab vestluse soome keele oskuse ja kasutuse kohta.

(10) A: Tere, käisime siis täna poliisis ja maistradis ära aga meie väga suureks üllatuseks selgub, et Eestis välja antud abielutunnistus ja lapse sünnitunnistus ei loe, need tuleb lasta kas inglise või soome keelde tõlkida ning notariaalselt kinnitada. Kui esimene korda kuu algusepoole poliisis käisime polnud sellest juttu. Hengelotunnused saame kätte alles siis kui tõlgitud ja notariaalselt kinnitatud tunnistused esitame.

C: Õige! Dokumendid peab olema ametliku tõlkija poolt tõlgitud ja notari kinnitatud. Ja mitte hengelotunnus, vaid henkilötunnus

A: Mis puutub õigesse hääldusesse ja kirjapilti siis olen soomes mõned nädalad ja puuudub soome keele oskus veel.

D: See hengelotunnus on $100 x$ parem kui inglitunnus :D

E: Keegi ei nori keeleoskamatuse pärast. See on lihtsalt tüüpiline sõna, mida ikka väänatakse ja käänatakse omamoodi. Vigadest õpitakse ja vast nüüd jääb meelde.

sm henkilötunnus 'isikukood'

Kuigi varases kontaktsituatsioonis on soome elementide kasutus pigem juhuslik ning ebareeglipärane, ei saa välistada, et mõned soome substantiivid on grupi liikmete kirjalikus kasutuses (ja ehk ka suulises kõnes) sel määral konventsionaliseerunud, et neid võidakse tajuda laensõnadena, mis asendavad eestikeelset 
omasõna ning mille kasutamine on kogukonnas norm. Sotsiaalmeedia (Facebooki) suhtlusgruppide kirjaliku keelekasutuse näitel võib selliste keelendite hulka lugeda järgmised: vero (tähenduses 'maksuamet'), maistraat (tähenduses 'rahvastikuregister') ja poliis (tähenduses 'politsei') või ka siinses artiklis vaatluse alla tulev alkolaen (veebi vahendusel alkoholi „laenamine“ ehk illegaalne alkoholi müük). Detailsema ülevaate Soomes elavate eesti keele kõnelejate suulisest keelekasutusest leiab Kristiina Praakli väitekirjast (2009) ning artiklitest $(2010,2014)$.

\section{Refereerimine koodivahetuse funktsioonina}

Järgnevalt vaatlen, kuidas kasutavad eesti keele kõnelejad koodivahetust eri funktsioonides. Koodivahetuse funktsioonide käsitluste tuntuimad teoreetikud on John J. Gumperz (1982) ning Peter Auer $(1995,1998)$. Eesti keeleteadlastest on koodivahetuse funktsioonidest detailse ülevaate andnud Anastassia Zabrodskaja (2006). Auer (1995) eristab koodivahetuse järgmised põhifunktsioonid, nagu refereerimine, vestluses osalejaskonna muutumine, vahelepõimedkõrvalmärkused, öeldu kordamine, rolli- ja teemavahetus, naljad ja keelemängud ning topikalisatsioon (lähemalt Praakli 2009: 102 ja sealsed viited). Mitmed loetletud funktsioonid, nagu näiteks refereeringud, naljad ja keelemängud, aga ka formaalsused (tervitused, pöördumised ja hüvastijätud) ning kultuurispetsiifiliste tekstide edastamine, nähtuvad ka selle artikli ainestikus, millest detailsemalt võtan vaatluse alla refereeringud.

Nii nagu ka suulise kõne puhul rakendatakse koodivahetust ennekõike refereerimise eesmärgil. Refereeritud kõne all mõistetakse ümberlülitumist teisele „häälel“", mis representeerib teist, kõneleja enda omast erinevat häält. Refereerimise abil tuuakse vestlusesse „kolmas" hääl, millega edastatakse, esitletakse ning taastoodetakse selles situatsioonis varasemad diskursused (Praakli 2009: 103 ja sealsed viited). Refereeringute avaldumist kirjeldan näidetes 11 ja 12 , pikemalt peatun teemal artikli viimases peatükis. 
Koodivahetusena avalduvates refereeringutes on üks enim esinev ütlus maassa maan tavalla (käitu maal selle maa kombel), millega viidatakse soovitusele järgida Soomes olles sealseid kombeid, traditsioone, kirjutamata reegleid jne. Näites 11 tekitab grupi liikmete seas pikema arutelu kortermaja stendil olev kiri pidevalt remonti tegeva korterielaniku aadressil. Kuigi kirja adressaati pole välja toodud, asuvad vestluses osalenud kohe seisukohale, et kriitika puudutab majas elavaid eestlasi.

(11) A: Jumala aus tekst.... pange silt üles, korraldage talgud ja ongi kõik hästi...;)

B: Tyypiline eestlane, kes ei arvesta naabritega, tehakse remonti ka peale 20.00, kui soomlane paneb lapsi magama

I...I

C: Selline tekst ei ole mingi üllatus, meil ka läbi elatud. Tundub tõesti olevat suisa tavapärane, et otse ütlemist välditakse. See on ehk üks suurim komistuskivi siin maal. Tasub aegsasti arvesse võtta ja siiski „maassa maan tavalla“ toimida...;) tähendab, muudame ennast, mitte teisi...

Soome maassa maan tavalla 'käitu maal selle maa kombel'

Analoogset üleminekut näeme ka näites 12, kus postituse autorile valmistab muret kultuurinormide mittetundmine (küsimus: kas Soomes tuleb esimesse klassi minnes ópetajale lilli viia?). Postituse autorile antud soovitus järgida riigis selle riigi kombeid ehk maassa maan tavalla edastatakse jällegi soome keeles. Ka siin tõstatub küsimus, miks teeb kõneleja seda soome keeles, kui tema keelelisse repertuaari kuuluvad ka eesti keele vahendid. Vestluse lõpetab tõdemine (E), et Soomes viiakse lilli vaid sünnipäevaks ja matustele.

(12) A: Öelge palun, kas Soomes on kombeks I klassi õpetajatele kooli alguses lilli viia? Eestis on, aga siinseid kombeid selle kohapealt ei tunne.

B: Ei tarvitse.:-

C: Poiss on su ju eestlane! Järgi meie tavasi ja kombeid $(-)$ Mis vahet sel on kas teised viivad või ei vii ${ }^{-}$ 
D: Minuarust lillede viimine on kyl kena komme. Aga eks need soomlased austavad ikka kui elatakse „maassa maan tavalla" ja kui siin kombeks pole nii muidugi natuke naljakas.

E: Soomes viiakse lill vaid sünnipäevaks ja matustele, muid variante ei ole.

Soome maassa maan tavalla 'käitu maal selle maa kombel'

Refereerimisel ning selle eri tähendustel, sh sotsiaalse tähenduse loomel, peatun detailsemalt artikli viimases peatükis.

Soome keelt võidakse vajadusel rakendada ka poeetilises ja/või humoorikas võtmes (näide 13). Üks grupi aktivistidest teeb võrgustiku liikmetele ettepaneku lasta fantaasial lennata ning kirjutada ühiselt luuletus. Järgmises näites näemegi, kuidas eesti keele kõnelejad rakendavad soome keele vahendeid poeetilisele keelele omaseid vormivõtteid riimi loomisel. Luulevormis avalduv koodivahetus on mitmetahulisem kui muud artiklis vaatluse all olnud näited, kuna need annavad lugejale rohkesti kontekstivihjeid öeldu tõlgendamise kohta, tähistavad aega ja ruumi ning paotavad ukse hargmaisesse elukorraldusse, kirjeldades piirideülese töörände eri aspekte.

(13) A: õhtust. igav on ja teeks õhtu huvitavaks. nimelt kuna siin on kõik nii andekad kommenteeriad siis kasutame seda ära ja laseme fantaasiat rakendada ka natuke asjalikumalt. vaatame mis kokku tuleb. teema siis fb ja seame riime ritta.. /.../ alustan siis ja iga järgmine kommenteerija lisab oma salmi.

B: Tõusen yles silmis sära,

kohe lähen tööle ära.

Õhtul koju tagasi,

miskipärast kõik päevad sedasi.

Võtsin võlgu tulles Soome,

kogu palga sõpradega maha joome.

Segutegemisel aitab internet,

kiirteel peatab mind ment.

Sakko mulle kirjutab,

mina rõõmsalt meenutan. 


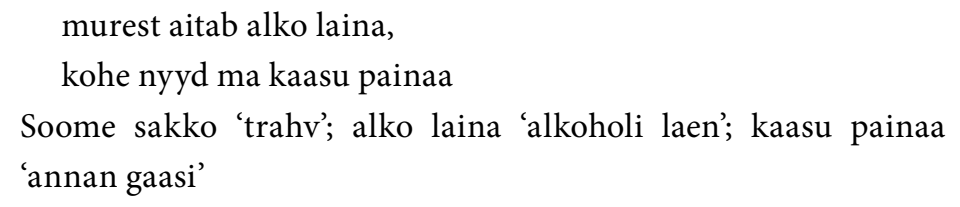

Nagu näeme, rakendab postitaja soome keele vahendeid ka riimiloomes: murest aitab alko laina, kohe nyyd ma kaasu painaa (murest aitab alkoholi laenamine, kohe nüüd ma gaasi annan). Koodivahetus põhineb soome keele foneetilisel materjalil (laina-painaa), kuigi teksti autor ei järgi koodivahetuses tingimata soome keele morfoloogilist struktuuri (vrd sm kaasua painaa). Koodivahetuses nähtub ka soome keele kasutamine rühmasisese koodina, mis hoolimata soome keele vahendite kasutusest ei pruugi olla soome keelt emakeelena kõnelejatele konteksti tundmata mõistetav. Nimelt mõistetakse eestikeelse fraasi „alkolaen“ all Eestist toodud alkoholi ebaseaduslikku müüki, mis toimub alkoholi laenamise nime all. Nii seda kui eelpool nimetatud substantiive poliisi, maistraati ja vero võib pidada konventsionaliseerunud laensõnadeks Soomega seotud eestlaste keeles.

Nagu näidetest nähtub, toimub üleminek soome keelele paljudel põhjustel. Küllap võivad mõningad ümberlülitumised johtuda ka asjaolust, et kõneleja emakeeles puuduvad mingis teemavaldkonnas edukaks kommunikatsiooniks vajalikud keelelised vahendid, kuid see pole esmatähtis. Olulisem näib olevat tõsiasi, et soome keel on grupi liikmete ühine suhtluskood, mistõttu on soome keele kasutamine ootuspärane ning aktsepteeritud ja mis teeb võimalikuks info edastamise võrgustiku liikmetele nende ühises, üldjuhul kõigile mõistetavas koodis. Ühesõnalised substantiivid toimivad edukalt ka rühmade eristaja ja markeerijana, tõmmates piiri meie ja teiste vahele, on asukohariigi- ja kultuurispetsiifilised, viitavad vestluse toimumise asukohale ning kontekstile laiemas mõttes. Samas näivad mitmed keelendid olevat konventsionaliseerunud või kannavad võrgustiku liikmete vahelises suhtluses sotsiaalses mõttes olulist tähendust. Teemat käsitlen pikemalt artikli viimases peatükis. 


\section{Koodivahetuse mitmehäälsus}

Koodivahetus on heteroglossiline vahend, mille all mõistetakse eri häälte ning diskursuste paljusust. Selles ühinevad vestluses osalejate hääled, sellega taasluuakse, edastatakse või esitletakse tähendust, mis on omakorda seotud varasemate diskursustega. Seega ei tähenda koodivahetus ainult öeldu edastamist, vaid selle abil toimub ka tähenduse loomine.

Vaatluse all olevast ainestikust nähtub, et kõnelejad edastavad keeleliste vahendite abil soomlaste võimalikku suhtumist eesti keele kõnelejate aadressil. Üks selline keelekasutuse sotsiaalset tähendust kandev keelend on soome kõnekeeles levinud kirumisväljend saatanan virolaiset (kuradi eestlased, saatana eestlased). Keelend on eestlaste omavahelistes vestlustes aktiivselt kasutuses, seda rakendatakse eestlastele kui rühmale viitamise vahendina, millega edastatakse enamusrühma arvumusi või suhtumist vähemusrühma suhtes. Vale pole ilmselt ka väita, et keelend ja selle variatsioonid (satana, saadana jne) kannavad eesti keele kõnelejate jaoks spetsiifilist tähendust, mida kasutades viidatakse endale kui rühmale, kõneldes samal ajal soomlaste häälega. Keelendi kasutuses nähtub ka teatav iroonia enamusrühma aadressil.

Koodivahetuses avalduvat mitmehäälsust olen valinud kirjeldama näited 14 ja 15 . Näites 14 kirjeldab vestluse algatanud eestlanna vahejuhtumit ühistranspordis: alkoholijoobes soomlannale avaliku korra rikkumise kohta märkuse teinuna oli ta sunnitud kuulama soomlanna kommentaare eestlaste aadressil.

(14) A: Hei, kaasmaalased!!! Reedene õhtu, sõidan koju peale tööd. Bussis kõrval istub purjus soome naine, kes hakkab ülbitsema. Mina loen, kuid ülbitsemine käib pinda ja palun oma rahu bussis. Mille peale hakkab karjuma, et olen virolais värdjas ja mingu tagasi kopikate eest töötama kodumaale. /.../ Kuidas Teie kaitsete ennast sellistel juhtudel?

I...l 
D: ma kutsuks poliisi, nad ei tohi ka Soomes teisi tylitada. Ja ma ei hakkaks yldse seda loba kuulama, vaid teeks kohe kõne.

B: Parem olla Virolainene värdjas kuis Kodimainene - asotsiaal

C: Sama kutsuks politsei neid nad kardavad kui veel purjus

D: Õige! Maassa maan tavalla!!!

E: ütle et saatana kehitysvammainen mene sairalaan ja hoitaa omia onkelmia sielä!

F: Dai boh kui yritab minna saatana virosse odavat õlut ostma I...।

G: Inimesed ma olen Teie üle uhke:nii huumorit, kaastannut ja tuge!!!-) Happy to be „virolais värdjas“ |...।

E: Olen kahjuks koos õega sellises olukorras olnud. Nimelt olime Koivukyla koera-aedikus, kus yks koertest oli agressiivne ja kippus mu koerale kallale. I.../ Palusime sel meesterahval oma koer âra kutsuda, mille peale ta aint irvitas rõvedalt. Ja hakkas kena tekst pihta - see koer s88b su ära, saatana virolaine. /.../

Soome virolais, virolainen värdjas 'eesti, eestlasest värdjas'; kotimainen 'kohalik'; maassa maan tavalla 'käitu maal selle maa kombel'; saatanan Viro 'kuradi, pagana Eesti'; saatanan virolainen 'kuradi, pagana eestlane'

Vene dai boh 'annaks jumal'; inglise happy to be 'õnnelik olla'

Postitus algab autori eestikeelse pöördumisega võrgustiku liikmete poole (Hei, kaasmaalased!!!) ning jätkub vahejuhtumi kirjeldusega eesti keeles (aeg, tegevused, osalised, olukorra kirjeldus jne). Postituse viimases lauses esitab ta grupi liikmetele küsimuse, kuidas end sellistes olukordades kaitsta. Nagu võime postitusest näha, esitab autor vahejuhtumi üldise kirjelduse eesti keeles, vahetades koodi tema jaoks juhtumi olulisima sõnumi edastamisel, viitega rühmale: mille peale hakkab karjuma, et olen virolais värdjas. Koodi vahetades esitab autor soomekeelsena tema jaoks sõnumi olulisima infolise osa, markeerides koodivahetuse abil konflikti teise osapoole, enamusrühma esindaja arvamust Soomes elavate eestlaste suhtes. Soome keeles toimunud vahejuhtumit kirjeldades edastab postituse 
autor soomekeelsena vaid rahvust puudutava osa (virolais 'eesti'), vahejuhtumi muid aspekte taasesitleb autor eesti keeles. Järelikult kannab soome keele kasutamine selles vestluskontekstis postituse autori jaoks vahejuhtumi olulisimat sõnumit, mille ta edastab refereeringu vormis soome keeles. Tõsi, refereering on vaid osaline, koodivahetus ei hõlma sõnumi vahest kõige olulisimat keelendit millist soome keele vandesõna soomlanna eestlaste aadressil täpselt kasutas, edastades vestluse selle osa eesti keeles (värdjas). Vaadeldes koodivahetuse struktuuri lingvistilises mõttes, näeme, et tegu on fraasitasandil toimuva tsiteeringuga, kus soomekeelsena esitatakse rahvuse soomekeelne nimetus (virolais), pejoratiivse vandesõna esitab autor eestikeelsena. Nagu postitusest ilmekalt nähtub, pole seda tüüpi koodivahetuste puhul tegu ei vestlusstrateegia, leksikaalse lünga täitmise vms, vaid teadliku ümberlülitumisega soome keelele, eesmärgiga edastada soomekeelsena, autentsel terviklikul kujul kolmanda isiku öeldu.

Postituse autori koodivahetus ei jää selles paarikümne osalejaga vestluses ainsaks soome keele kasutuseks. Autorile sekundeerib kümmekond võrgustiku liiget, kelle puhul võib koodivahetuse rakendamises täheldada analoogset mustrit, kus etnilistele rühmadele viitamisel rakendatakse soome keele vahendeid. Mitmel juhul võib täheldada ka refereeringute kihistumist, kus kõneleja refereerib samaaegselt nii postituse autorit kui ka algsõnumit. Asjakohaseks näiteks on siin vestlusesse lülitunud grupi liikme B postitus, kelle koodivahetuses ühinevad nii postituse autori kui ka konflikti algatanud soomlanna "hääled": parem olla virolainene värdjas kui kodimainene - asotsiaal. Üleminekud toimivad selgelt rühma tähistajana, markeerides eri rühmi ja nende taustu soome keele vahenditega: virolainene (sm virolainen) versus kodimainene (sm kotimainen 'kodumaa, kodumaine') ehk eestlane kui sisserännanu ning soomlane kui põliselanik. Refereering on tähelepanuväärne ka keelelises mõttes. Üleminek soome keelele ei järgi kummagi keele kirjalikke norme, kahe keele vahendite baasil moodustub kolmas keelekuju. See, kas tegu on soome keele teadliku väärkasutusega või viitabki 
kõneleja soome keele kujule, jääb paraku teadmata. Samas ei saa välistada ka seda, et kõneleja viitab soome adjektiivisufiksi -nen teadliku väärkasutusega vestlust soomepärasemaks muutes nii eri rühmadele kui ka nende soome keele oskuse tasemele (eestlased on sisserännanud ega oska isegi soome keelt).

Enamus- ja vähemusrühma vahele tõmmatakse soome keelt kasutades piirid veel mitmes postituses. Analoogset üleminekut näeme ka F-i postituses. Tema keelelises esituses kandub vandesõnaga saatana edastatav pejoratiivne tähendus rahvuselt üle ka riigile (Dai boh kui yritab minna saatana virosse odavat õlut ostma). Vestlusesse sekkub postitaja $\mathrm{G}$, kes avaldab enda postitusega poolehoidu eeskõnelejatele ning tähistab soome keelele ülemineku jutumärkidega: Happy to be "virolais värdjas". Soome keele vahendeid kasutades viitab rahvusele veel ka postitaja E, kes kirjeldab temale osaks saanud vahejuhtumit soome kodanikuga, edastades soomekeelsena vestluse olulisima osa, viitega taaskord rahvusele: Ja hakkas kena tekst pihta - see koer s88b su ära, saatana virolaine.

Analoogne soome keele kasutus nähtub ka kahes järgmises näitelauses, kus rahvusele viidates kasutatakse taaskord soome keele vahendeid. Kaks järgmist vestlust erinevad eespool kirjeldatust selle poolest, et siin pole tegu konkreetse kolmanda isiku kõne refereerimisega (esimese näite puhul taasesitas postituse autor konkreetset vahejuhtumit, olles üks juhtumi osapooltest), vaid koodivahetuse kaudu edastatakse enamusrühma oletatavat arvamust või hinnangut eesti vähemusrühma aadressil, mida tehakse taaskord keelendi saatana vahendusel. Järgmises näites kirjeldab postituse autor elukoha registreerimise protseduuri ametiasutuses, edastades kõneleja hinnangul talle osaks saanud negatiivse kogemuse ametnikust, kes olevat vaadanud teda kui eesti päritolu inimest halvustava pilguga „saatana virolaiset".

(15) A: Käisime mehega just poliisis end siia elama registreerimas. Esialgu vaatas ametnik kohe pilguga „saatana virolaiset". /.../ soome saatanan virolaiset 'kuradi, pagana eestlased' 
Ka selles vestluskatkes toimub koodivahetus teadlikult ning esineb markeeritud kujul, mida kirjalikus vestluses markeerivad eri "häälte" eristajatena toimivad jutumärgid, mis toovad samaaegselt sisse nii oma kui ka võõra hääle, kuid mis lubavad kõnelejal ennast öeldust distantseerida (à la see on mitte minu, vaid soomlaste arvamus eestlaste kohta).

Viimane näide erineb eelmistest selle poolest, et postituses kirjeldatud tegevuses osalejateks (hernevargus) on eranditult eesti keele kõnelejad. Vestluse algataja postitab gruppi iroonilises võtmes kommentaari kaasmaalaste aadressil: Tervitan kõiki kaasmaalasi, kes praegu mul majalähedal herne raksus on. Postitust kommenteerivad rühma liikmed esitavad postituse autorile enda arvamused hernevargil käinute rahvuse või muude etniliste tunnuste põhjal (originaalpostitus on pikem kui siinne vestluskatke). Nii arvab postitaja B, et hernepõllul käijateks olid ehk moslemid, mille kohta postituse autor vastab koodi vahetades, et ei olnud, käijad olid täitsa satana virolaised. Ka siin pole koodivahetus enam pelk kahe keele vaheldumine, vaid teadlik soome keele vahendite rakendamine, millega kõneleja viitab eestlastele samu soome keeles levinud pejoratiivseid vahendeid kasutades.

(16) A: Tervitan kõiki kaasmaalasi, kes praegu mul majalähedal herne raksus on :))))

B: Need on moslemid

A: Ei ei $(-)$ Täitsa satana virolaised olid ... on ... raske nü̈̈d juba öelda ... võib olla juba järgmised.

Soome saatanan virolaiset 'kuradi, pagana eestlased'

\section{Kokkuvõte}

Artiklis oli vaatluse all Soomega eesti keele kõnelejate koodivahetus Facebooki-diskursuste näitel. Vaatluse all olnud keeleainestiku valguses võib koodivahetuse kohta esialgselt öelda järgmist. Soome keele rakendamine vestlustes on nii funktsioon, vestluse kontekstile viitaja, kõneleja identiteedi tähistaja, rühmade eristaja 
kui ka rühmadevaheliste piiride tõmbaja. Mitmekeelsetes suhtlusolukordades saab koodivahetusest ka sotsiaalne akt, mis kannab, edastab, toodab ja taastoodab tähendusi. Koodivahetus on ühtlasi mitme häälega kõnelemine, milles põimuvad kõnelejate kultuuriliskeelelised kogemused. Võrgustiku liikmete puhul on selgelt näha, et koodivahetus on aktsepteeritud keelelise käitumise viis ning koodivahetuse kasutamine on norm. Seda ka olukorras, kus kõnelejal puudub igasugune soome keele oskus, mis pole aga takistuseks kommunikatsioonis edukalt toimimiseks. Samas on eesti keele kõnelejate kirjalikus suhtluses nähtav variatiivsus ning ebasümmeetria soome keele kasutuses (laiemas mõttes soome keele oskuses) üks grupi liikmete positsioneerimise ning staatuse näitamise vahendeid. Selles võib näha ka teatavat jõu ja võimu vahendit, eri rühmade (eestlased ühel- ja teiselpool Soome lahte) ja/või eluolukordade eristajat.

\section{KIRJANDUS}

Androutsopoulos, Jannis 2013. Networked multilingualism: Some language practices on Facebook and their implications. - International Journal of Bilingualism, 1-21.

Auer, Peter 1995. The pragmatics of code-switching: a sequential approach. One speaker, Two languages: Cross-Disciplinary Perspectives on CodeSwitching. Eds. Lesley Milroy, Pieter Muysken. Cambridge: Cambridge University Press, 115-135.

Auer, Peter 1998 (ed.). Code-Switching in Conversation: language, interaction and identity. London: Routledge.

Auer, Peter 2013. Code-switching/mixing. - The SAGE Handbook of Sociolinguistics. Edits. Ruth Wodak, Barbara Johnstone, Paul Kerswill. SAGE Publications ldt, 460-478.

Gumperz, John J. 1982. Discourse Strategies. Cambridge University Press.

Ehala, Martin; Koreinik, Kadri; Praakli, Kristiina; Siiner, Maarja 2014. Kuidas uurida keele kestlikkust? - Keel ja Kirjandus 7, 489-508.

Frick, Maria 2009. Morphological integration of Estonian lexical elements in a Finnish language base during the first years of immigration. - Journal of Linguistic and Intercultural Education 1, 81-95. 
Frick, Maria 2010. Suomi-viro koodinvaihto Facebookissa. - Lähivõrdlusi. Lähivertailuja 20. Toim. Eve Mikone, Kirsti Siitonen, Maria-Maren Sepper. Tallinn: Eesti keele sihtasutus, 49-67.

Frick, Maria. 2013. Emergent bilingual constructions: Finnish-Estonian codeswitching in interaction. Doctoral dissertation. Helsinki: University of Helsinki.

García, Ofelia; Wei, Li 2014. Translanguaging: Language, Bilingualism and Education. Basingstoke: Palgrave Macmillan.

Hansalu, Kadri 2015. Eestis on 590000 Facebooki kasutajat. http://majandus24.postimees.ee/3415827/eestis-on-590-000-facebooki-kasutajat (24.04.2016)

Härmävaara, Hanna-Ilona; Frick, Maria. Handling linguistic asymmetries by bilingual punning in conversations among speakers of cognate languages. - Crossing Languages to Play with Words: Interdisciplinary Perspectives. Eds. Sebastian Knospe, Alexander Onysko, Maik Goth. Berlin: DeGruyter. [ilmumas].

Jakobson, Mari-Liis; Järvinen-Alenius, Pauliina; Pitkänen, Pirkko; Ruutsoo, Rein; Keski-Hirvelä, Elisa; Kalev, Leif 2012. The Emergence of EstonianFinnish Transnational Space. - Migration and Transformation: MultiLevel Analysis of Migrant Transnationalism. Eds. Pirkko Pitkänen, Ahmet İçduygu, Deniz Sert. Book Series: International Perspectives on Migration. Springer-Verlag. (International Perspectives on Migration), 159-206. [ilmumas]

Jørgensen, Jens Norman 2008. Polylingual languaging around and among children and adolescents. - International Journal of Multilingualism vol. 5:3, 161-176

Jørgensen, J. Normann; Karrebæk, Martha Sif; Madsen, Lian Malai; Møller, Janus Spindler 2011. Polylanguaging in superdiversity. - Diversities Journal Fall 2011, 32-54.

Kärkkäinen, Henrik 2015. Facebook paljasti Suomi-lukuja. http://www. itviikko.fi/uutiset/2015/04/15/facebook-paljasti-suomi-lukuja/ 20154707/7 (23.04.2016)

Koreinik, Kadri; Praakli, Kristiina 2016. Emerging language political agency among Estonian native speakers in Finland. - Language Policy Beyond the State. Eds. Maarja Siiner, Kara D Brown, Kadri Koreinik. Springer Netherlands. (Language Policy ) [ilmumas]. 
Lehtonen, Heini 2015. Tyylitellen: Nuorten kielelliset resurssit ja kielen sosiaalinen indeksisyys monietnisessä Helsingissä. Väitöskirja. Helsinki: Helsingin yliopisto.

Otsuji, Emi; Pennycook, Alastair 2010. Metrolingualism: fixity, fluidity and language in flux. - International Journal of Multilingualism 7:3, 240-254.

Praakli, Kristiina 2009. Esimese põlvkonna Soome eestlaste kakskeelne keelekasutus ja koodikopeerimine. Tartu: Tartu Ülikooli Kirjastus.

Praakli, Kristiina 2010. Eestlased ja eesti keel Soomes. - Eestlased ja eesti keel välismaal. Toim Kristiina Praakli, Jüri Viikberg. Tallinn: Eesti Keele Sihtasutus, 455-501.

Praakli, Kristiina 2014. On the bilingual language use of the Estonianspeakers in Finland. - Sociolinguistic Studies 8 (3). 383-409.

Riionheimo, Helka 2007: Muutoksen monet juuret. Oman ja vieraan risteytyminen Viron inkerinsuomalaisten imperfektin muodostuksessa. Suomalaisen Kirjallisuuden Seuran Toimituksia 1107. Helsinki: Suomalaisen Kirjallisuuden Seura.

Riionheimo, Helka 2009: Interference and attrition in inflectional morphology. A theoretical perspective. Language contacts meet English dialects: Studies in honour of Markku Filppula. Eds. Esa Penttilä, Heli Paulasto. Newcastle: Cambridge Scholars Publishing. 83-104.

Riionheimo, Helka 2011. Complex morphologies in contact. The case of Ingrian Finns in Estonia. - Language contact and language shift. Grammatical and sociolinguistic perspectives. Ed. Kelechukwu Ihemere. Munich: LINCOM Publishers. 10-36.

Riionheimo, Helka 2013a: Inkerinsuomen verbimorfologia kielikontaktissa ja attritiossa. - Rapautuva kieli. Suomalaisen Kirjallisuuden Seuran Toimituksia 1404. Toim. Kimmo Granqvist, Päivi Rainò. Helsinki: Suomalaisen Kirjallisuuden Seura. 37-74.

Riionheimo, Helka; Frick, Maria 2014. The emergence of Finnish-Estonian bilingual constructions in two contact settings. - Sociolinguistic Studies 8(3) Equinox Publishing Ltd. 409-447.

Zabrodskaja, Anastassia 2006. Vene-eesti koodivahetuse funktsioonid Kohtla-Järve venekeelsete laste vestluses. - Eesti Rakenduslingvistika Ühingu aastaraamat 2. Toim. Maria-Maren Sepper, Helle Metslang, Margit Langemets. Tallinn: Eesti Keele Sihtasutus 231-249. 
Tilastokeskus 2016=Tilastokeskuksen PX-Web-tietokannat $\rightarrow \mathrm{Px}-$ Web StatFin $\rightarrow$ Väestö $\rightarrow$ Väestörakenne. Kieli iän ja sukupuolen mukaan maakunnittain 1990-2015. http://www.tilastokeskus.fi/tup/tilastotietokannat/index.html. (15.08.2016)

Verschik, Anna 2008. Emerging bilingual Speech. From Monolingualism to Code-Copying. London, New York: Continuum. 